\title{
林暁洋 学位論文審査要旨
}

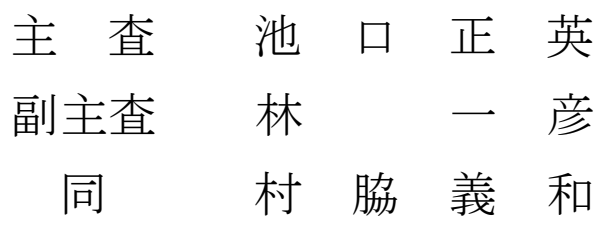

\section{主論文}

Fhit, E-cadherin, p53, and activation-induced cytidine deaminase expression in endoscopically resected early stage esophageal squamous neoplasia

（内視鏡的に切除された早期食道扁平上皮性腫瘍でのFhit、E-cadherin、p53、AIDの蛋白 発現)

（著者：林暁洋、八島一夫、武田洋平、佐々木修治、河口岡一郎、原田賢一、村脇義和、 井藤久雄)

平成24年 Journal of Gastroenterology and Hepatology 掲載予定 


\section{学 位 論 文 要 旨}

Fhit, E-cadherin, p53, and activation-induced cytidine deaminase expression in endoscopically resected early stage esophageal squamous neoplasia （内視鏡的に切除された早期食道扁平上皮性腫瘍でのFhit、E-cadherin、p53、AIDの蛋白 発現）

食道扁平上皮癌は、飲酒・喫煙などが危険因子であるが、通常低異型度上皮内腫瘍から 高異型度上皮内腫瘍/上皮内癌となり、浸潤癌へと進展していく。この際には、複数の遺伝 子異常が蓄積することが知られており、p53などの細胞周期関連因子やE-cadherinなどの細 胞間接着分子などの関与が報告されている。癌抑制遺伝子のFHIT遺伝子は飲酒、喫煙など により欠失やメチル化が生じ、発癌の早期で重要と考えられている。遺伝子編集酵素のAID は、胃癌においてHelicobacter pylori感染によりAIDの異常発現を誘導し、p53などの癌関 連遺伝子に変異を生じさせることが明らかになっている。本研究では、癌関連蛋白である Fhit、E-cadherin、p53、AIDの発現異常と食道扁平上皮性腫瘍の進展との関係を明らかに するため、内視鏡的に切除された標本を用いてこれらの蛋白発現を調べ、臨床病理学的背 景との関係を比較検討した。

\section{方 法}

対象は2004年から2010年までに、鳥取大学医学部附属病院消化器内科にて内視鏡的に切 除された食道扁平上皮性腫瘍41症例 (男性39例:女性2例、平均年齢69歳) 49病変で、病変は 低異型度上皮内腫瘍が 9 例、高異型度上皮内腫瘍/上皮内癌が 22 例、浸潤癌 18 例である。免 疫組織化学染色法によるFhit、E-cadherin、p53、AIDの蛋白発現と患者背景 (喫煙・飲酒状 況)、臨床病理学的背景 (深達度、部位、肉眼型など) との関係を検討した。

\section{結 果}

Fhit、E-cadherinの蛋白発現異常 (減弱または消失) は、それぞれ低異型度上皮内腫瘍で 22\%、0\%、高異型度上皮内腫瘍/上皮内癌で73\%、14\%、浸潤癌で $94 \%$ 、61\%であり、低異型度 上皮内腫瘍から浸潤癌への進行に伴い、両者の蛋白発現異常の頻度は高くなった。p53、AID の蛋白発現異常は、低異型度上皮内腫瘍、高異型度上皮内腫瘍/上皮内癌、浸潤癌で明らか な差はなく、全体で各々 $47 \%$ 、41\%であった。これらの癌関連蛋白発現と他の臨床病理学的 
背景との間に有意な関連は認めなかった。また、胃癌ではp53とAIDの密接な関連が知られ ているが、今回の早期食道扁平上皮性腫瘍ではp53とAID発現との関係は認めなかった。飲 酒・喫煙との関係では、Fhit蛋白発現異常例において、平均飲酒指数 (728vs 457; p=0.061) および平均ブリンクマン指数 (855 vs $751 ; \mathrm{p}=0.084$ ) が高い傾向を認めた。

\section{考 察}

Fhit蛋白の発現異常頻度は、低異型度上皮内腫瘍から浸潤癌に進行するに伴い、高くな った。これまでにも外科的切除された浸潤癌とそれに伴う上皮内腫瘍病変においてのFhit 蛋白の発現異常の報告例があるが、今回の結果とほぼ同様であった。したがって、Fhit蛋 白発現は、早期の食道扁平上皮癌の進展、特に低異型度上皮内腫瘍から高異型度上皮内腫 瘍/上皮内癌への進展に関与している可能性が示唆された。また、従来の報告と同様に、Fhit 蛋白の発現減弱は、飲酒・喫煙などの環境因子と関連が認められ、FHIT遺伝子が食道扁平 上皮癌の発生・進展における分子的標的の一つと考えられた。

E-cadherin蛋白の発現異常頻度は浸潤癌で高く、特に高異型度上皮内腫瘍/上皮内癌から 浸潤癌への進行に関与していることが考えられた。さらに、Fhit、E-cadherinの両蛋白発 現の正常例は、低異型度上皮内腫瘍または高異型度上皮内腫瘍/上皮内癌であるのに対して、 両蛋白発現の減弱・消失例は83\%が浸潤癌であった。このことから、Fhit、E-cadherinの蛋 白発現の検討は、浸潤癌への進行を予測できる可能性が示唆された。なお、p53、AID蛋白 の異常発現は、進行程度で差は認めず、また両者に関連を認めなかった。

\section{結 論}

FhitおよびE-cadherinの蛋白発現減弱が、食道扁平上皮癌の発生、進展に関与していた。 この結果は、食道扁平上皮癌の早期診断、治療方針の決定に寄与寸る可能性が示唆された。 